\title{
Upaya Guru dalam Mengatasi Perilaku Bullying Siswa di SMAN 7 Padang
}

\author{
Ririn Oktavia, Susi Fitria Dewi \\ Prodi Pendidikan Pancasila dan Kewarganegaraan \\ FIS Universitas Negeri Padang \\ E-mail: susifitria@gmail.com
}

\section{ABSTRAK}

Bullying adalah sebuah kata serapan dari bahasa inggris. Istilah bullying biasa diartikan sebagai perundungan. Perundungan yaitu sebuah pengertakan atau orang yang lemah. Perundungan merupakan prilaku agresif dan negatif seorang yang menyalahgunakan kekuatan yamg dimiliki untuk menyakiti targetnya. Dari hasil peneliti yang didapatkan ada beberapa prilaku perundungan yang pernah di lakukan oleh siswa SMA N 7 Padang. Penelitian ini menggunakan pendekatan kualitatif yang bersifat deskriptif. Teknik pengumpulan data penelitian yaitu dengan wawancara, observasi, dan dokumentasi. Informan dalam kegiatan wawacara yaitu, Guru Pkn, Guru Bk, dan siswa. Perilaku perundungan atau bullying tersebut berupa mengolok-olok temannya yang tampil, memanggil panggilan yang tidak disenangi. Dalam hal itu membuat si korban tidak nyaman dengan panggilan tersebut. Terdapat beberapa upaya terutama guru PKn mengatasi perilaku perundungan bullying yaitu menegur yang membully, dan memberikan arahan bahwa perilaku itu tidak pantas dikerjakan dan jika hal itu masih terulang kembali guru menindak lanjutan ke guru BK serta memberitahu orang tuanya.

Kata Kunci: perundungan, bullying, SMAN 7 Padang, siswa

\section{ABSTRACT}

The term bullying can also be interpreted as bullying. Bullying is a person who is weak. Bullying is a negative and aggressive behavior of a person who misuses the power he has to hurt his target. From the research results, it was found that there were several bullying behaviors that had been done by SMA N 7 Padang students. This research uses a descriptive qualitative approach. Data collection by interview, observation, and documentation. The informants in the interview activities were the teachers and students. The bullying is in the form of making fun of his friends who appear, calling calls that are not liked. In that case it makes the victim uncomfortable with the call. There are several efforts, especially civics teachers to overcome bullying behavior, namely reprimanding bullies, and giving directions that the behavior is inappropriate to do and if it is repeated, the teacher follows up to the Guidance and Counselling teacher and informs their parent.

Keywords: bullying, SMAN 7 Padang, students

(c) (1) (9) This work is licensed under the Creative Commons Attribution-ShareAlike 4.0 International License. (C)2020 by author. 


\section{PENDAHULUAN}

Pendidikan merupakan kebutuhan setiap diri manusia, dimana terjadi timbal balik antara pendidik dan peserta didik. Pendidikan berperan penting dalam membekali setiap diri manusia agar menjadi pribadi yang terpelajar dan berwawasan luas. Menurut Berg (dalam Ismail, 2019) menjadi orang yang berpendidikan berarti manusia menjadi proses pencerdasan dan pengembangan potensi secara kontinyu dan optimum.

Dalam mencapai Pendidikan banyaknya rintangan yang akan dihadapi. Salah satunya adalah masalah yang dihadapi oleh peserta didik itu sendiri, yang mana masalah yang sering dihadapi yaitu perilaku bullying siswa yang sangat merugikan pada diri siswa itu sendiri. Bullying adalah sebuah kata serapan dari bahasa inggris. Bullying juga diartikan sebagai perundungan. Secara psikologis, perundungan atau bullying adalah ekspresi muka yang merendahkan, kasar atau tidak sopan, mempermalukan, dan mengucilkan. Perundungan adalah prilaku agresif dan negatif seseorang atau sekelompok orang yang menyalahgunakan kekuatan yang memiliki tujuan untuk menyakiti targetnya (korban) secara mental maupun secara fisik (Tisna, dalam Trisnani 2016). Perilaku bullying merupakan salah satu bentuk kekerasan dan agresif siswa di sekolah ( Yenes, 2016).

Bentuk bullying terdiri dari bullying verbal, fisik, dan bullying psikologis. Bullying disekolah kebanyakan berasal dari teman sebaya, bahkan dari kakak kelas, mereka berkeinginan untuk melanjutkan tradisi atau ingin berkuasa mencari popularitas dengan melakukan tindakan intimidasi kepada pihak yang lebih lemah (Astuti, 2008). Bullying merupakan salah satu bentuk kenakalan remaja.

Dampak yang terjadi pada korban bullying yaitu timbulnya emosi negatif (marah, dendam, tertekan, malu, dan sedih). Faktor dari perilaku bullying disebabkan oleh adanya pengaruh teman sebaya yang menimbulkan pengaruh negatif melalui cara menghasut bahwa bullying bukan suatu masalah besar melainkan hal yang wajar untuk dilakukan. Anak yang menjadi korban bullying akan mengalami kesulitan dalam bergaul, merasa takut datang ke sekolah sehingga absensi mereka tinggi dan tertinggal pelajaran, dan mengalami kesulitan berkonsentrasi dalam mengikuti pelajaran sehingga kan mempengaruhi prestasi belajar yang akan dicapai anak tersebut (Rigby, dalam Dwipayanti 2014). Seperti halnya yang dikemukakan oleh (Hakim, dalam Dwipanti 2014) konsentrasi adalah salah satu faktor keberhasilan siswa.

Sebagai perilaku agresif, bullying tidak bisa didiamkan dan diabaikan begitu saja. Perlu adanya upaya dari bebagai pihak untuk mengatasi bullying yang terjadi di sekolah, salah satunya yaitu diperlukan peran dari guru PPKn dan guru BK.

Guru sebagai pendidik yang ada di lembaga sekolah harus mempunyai teknik dan strategi untuk dapat mengatasi perilaku bullying di sekolah. Dalam Pasal 4 UU No. 23 
Tahun 2002 tentang Perlindungan Anak, menyebutkan bahwa anak mempunyai hak untuk hidup dapat hidup tumbuh, berkembang dan berpartisipasi secara wajar sesuai harkat dan martabat kemanusian serta mendapatkan prlindungan dari segala diskriminasi dan segala jenis tindakan kekerasan pada diri anak yang nisa disebut dengan bullying. Peranan guru disekolah adalah sebagai pegawai dalam hubungan kedinasan, sebagai pendidik dalam hubungannya dengan siswa, sebagai pengatur disiplin, dan sebagai pengganti orangtua. Seorang guru difungsikan untuk mengendalikan, memimpin dan mengarahkan events (waktu) pengajaran.

\section{METODE PENELITIAN}

Jenis penelitian ini adalah penelitian kualitatif deskriptif yang bertujuan mendeskripsikan dan menggambarkan secara sistematis terkait fakta yang sebenarnya. Menurut Denzin dan Lincoln (dalam Moleong, 2013) penelitian kualitatif adalah penelitian yang menggunakan latar alamiah dengan maksud menafsirkan fenomena yang terjadi dengan melibatkan berbagai metode yang ada. Penelitian kualitatif memperoleh data sebagaimana mestinya, bukan berdasarkan apa yang difikirkan oleh peneliti.

Lokasi penelitian berada di SMA Negeri 7 Padang Jalan Bunga Tanjung Kelurahan Batipuh Panjang Kecamatan Koto Tangah Kota Padang Sumatera Barat. Oleh karena itu sesuai dengan fokus peneliti, subjek yang akan dijadikan informan yaitu Guru PPkn, Guru BK dan Siswa.

\section{HASIL DAN PEMBAHASAN}

Penelitian ini dilakukan pada masa pandemi Covid-19. Maka dari itu peneliti melakukan wawancara hanya beberapa guru yang terkait dengan informan peneliti. Pada masa melakukan obeservasi terdapat perilaku bullying yang pernah terjadi di SMA N 7 Padang. Jenis bullying yang sering terjadi yaitu bullying verbal.

Menurut Sanjaya (dalam Nurussama, 2009) guru sebagai pendidik mengandung arti yang sangat luas, tidak sebatas memberikan bahanbahan pengajaran, tetapi menjangkau etika dan estetika perilaku dalam menghadapi tantangan kehidupan di masyarakat.

Dalam hal ini adanya terdapat upaya guru dalam mengatasi bullying tersebut seperti:

\section{Menerapkan Anti-bullying}

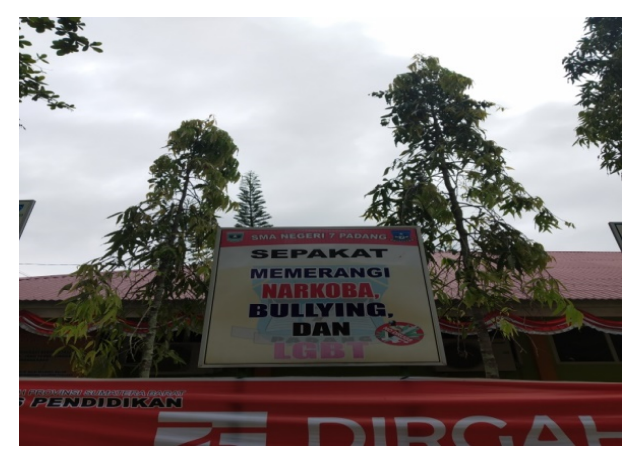

Gambar.1

Salah satu upaya yang dilakukan sekolah dalam mengatasi perilaku bullying yaitu menerapkan slogan "Sepakat Memerangi Narkoba, Bullying dan LGBT". Upaya ini dirancang untuk pemahaman kepada semua pihak sekolah, guru, staf sekolah maupun siswa keas $\mathrm{X}, \mathrm{XI}$,dan XII. Slogan tersebut menjadikan perhatian oleh murid karena posisinya berada di jalan masuk ke 
sekolah. Dengan harapan siswa bisa memotivasi dirinya sendiri, dan adanya rasa solidaritas antar siswa untuk tidak melakukan tindakan bullying. Slogan ini dikaitkan dengan materi pembelajaran PPKn dan juga pada saat pembelajaran $\mathrm{BK}$.

\section{Teguran Langsung}

Memberikan teguran langsung berupa nasehat kepada siswa yang melakukan bullying yakni dengan memberikan motivasi agar menghindar dari perilaku bullying yang telah ditetapkan di sekolah yaitu berbentu slogan anti-bullying tersebut.

Himbauan dari luar untuk
menerapkan anti-bullying

Upaya yang dilakukan oleh sekolah yaitu memanggil pihak luar untuk menerapakan anti-bullying di SMA N 7 Padang. Hal itu bertujuan agar siswa mengetahui seberapa pentinganya kita mengetahui efek dari melakukan tindakan perilaku bullying tersebut.

Penanganan oleh guru Bimbingan Konseling

Dalam perilaku bullying ini guru BK sangat berperan dalam penanganan kasus yang pernah terjadi. Dikarenakan siswa lebih terbuka membicarakan masalah yang sedang dihadapinya baik itu masalah sama teman maupun keluarga. Adapun penanganan yang dilakukan oleh guru BK jika terjadi permasalahan pada siswa yakni: a) Menanamkan rasa percaya diri. Guru BK tersebut tidak hanya menerapkan rasa percaya diri kepada korban, akan tetapi juga menerapakan rasa percaya diri kepada pelaku, bahwasannya dibalik teman yang di-bully tersebut pasti dia memiliki kelebihan. b) Mencari tahu akar permasalahan.

Sebelum mengatasi lebih lanjut guru BK terlebih dahulu mencari tahu akar dari permasalahan yang dialami oleh siswa. c) menerapkan sebuah permainan yang bertemakan atau berkaitan dengan anti-bullying. Dengan menerapkan permainan, siswa-siswa tersebut mengetahui apaapa saja hal yang harus kita terapkan dalam mengantisipasi terjadinya bullying disekolah. Guru sebagai pendidik tidak hanya bertanggung jawab pada nilai akademis siswa, tetapi juga dalam bentuk tingkah laku dan karakter siswa. Dalam kasus ini guru berhak merespon dan segera melakukan tindakan untuk mengatasi terjadinya bullying siswa tersebut.

Dalam skripsi Indawati (2016), mengatakan bahwa upaya yang dilakukan oleh guru dalam mengatasi perilaku bullying yaitu memanggil siswa yang bersangkutan, memasukan dalam buku catatan BK, siswa yang meiliki permasalahan dipanggil satu-satu, mencari tahu masalah yang terjadi, mengklasifikasi masalah tersebut. Korban maupun pelaku dipanggil, lalu ditanyakan "benar melakukan apa tidak", dan kedua pihak didamaikan melalui kesepakatan supaya tidak mengulanginya kembali.

Menurut Putri (2016), strategi guru dalam mengatasi perilaku bullying yaitu: mencari akar permasalahan seperti seputar alasan siswa melakukan bullying, memberikan hukuman, membuat kelompok belajar, menasehati/memberikan himbauan kepada siswa pelaku bullying maupun siswa yang berpotensi menjadi pelaku bullying, memberikan layanan, memberikan penghargaan, menerapkan program "stop bullying".

Lain halnya upaya guru untuk menanggulangi perilaku bullying atau 
bahkan perilaku menyimpang yaitu terdapat dalam Mudjira,dkk 2018: Pertama, menegakan disiplin sekolah. Penegakan disiplin berlaku untuk semua personil sekolah. Bagi siswa, perlu ketertiban pakaian seragam sekolah, kehadiran dan pulang sekolah serta penegakan peraturanperaturan sekolah. Penegakan disiplin bagi guru dimaksudkan agar tidak terlalu banyak jam belajar yang hilang disebabkan guru masuk/ tidak datang mengajar. Ini mengakibatkan siswa menganggur dan ribut atau keluyuran.

Kedua, membantu mengatasi masalah yang dialami siswa. Salah satu sumber perilaku menyimpang yaitu siswa menghadapi masalah yang tidak terpecahkan. Oleh karena itu, pihak sekolah melalui guru pembimbing dan guru mata pelajaran membantu mengatasi masalah dan kesulitan belajar yang dialami siswa.

Ketiga, menyediakan fasilitas, sarana, dan prasaran belajar. Sekolah secara bertahap perlu melengkapi fasilitas, sarana dan prasarana belajar agar proses belajar-mengajar dan kegiatan sekolah lainnya dapat berjalan dengan baik. Siswa dapat menyalurkan kegemarannya. Ini dapat mengurangi aktivitas siswa yang negatif.

Keempat, menjalin kerjasma dengan berbagai pihak terkait. Untuk kemajuan sekolah dan menghindari serta mengatasi perilaku menyimpang, perlu menjalin hubungan dan kerjasama yang intensif dengan para orang tua siswa, masyarakat, lingkungan sekolah, dan instansi lain yang terkait, seperti polisian, puskesmas, dan sebagainya. Dengan hal tersebut perilaku menyimpang akan jauh terhindar dari kalangan remaja baik di lingkungan sekolah maupun diluar sekolah. Karena siswa-siswa selalu diawasi atau dipantau keberadaan dan aktivitasny. Masyarakat juga berhak mengawasi hal-hal yang berbau menyimpang yang terjadi pada remaja.

\section{KESIMPULAN}

Upaya dilakukan oleh sekolah dalam mengatasi perilaku bullying yaitu dengan cara menerapkan slogan anti-bullying, yang bertujuan agar siswa selalu menjauhi bullying di sekolah baik dalam lingkungan sekolah maupun diluar lingkungan sekolah, melakukan teguran langsung kepada siswa yang melakukan bullying atau hal-hal yang tidak boleh dilakukan yang bisa menyakiti hati orang lain, hal tersebut bertujuan untuk memberikan efek jera kepada siswa untuk tidak melakukannya kembali.

Selain itu guru mendatangkan orang dari luar pihak sekolah, seperti yang pernah dilakukan yaitu memanggil salah satu Kapolsek Koto Tangah untuk mengingatkan siswa agar menerapkan anti-bullying disekolah, dan melakukan penanganan oleh guru BK. Dalam menerapkan hal tersebut diharapkan kepada siswa untuk tidak melakukan tindakan bullying baik dalam sekolah maupun diluar sekolah karena itu sangat membahayakan baik untuk diri sendiri, orang lain bahkan banyak orang.

\section{DAFTAR PUSTAKA}

Astuti, Ponny Retno. 2017. Meredam

Bullying tiga Cara Efektif

Menanggulangi Kekerasan Pada

Anak. Jakarta: Grasindo, IKAPI

Putri, Fellinda Arini. 2016. Strategi

Guru Dalam Mengatasi Perilau 
86 | upaya guru dalam..

Bullying Di SMP Negeri 1 Mojokerto. Kajian Moral dan Kewarganegaraan Vol 01 N0 04 Tahun 2016, 62-76

Zakiyah, Ela Zain, dkk.. 2017. Faktor Yang Mempengaruhi Remaja Dalam Melakukan Bullying. Jurnal Penelitian \& PPM Vol 4 N0 2 ISSN:2442-448X Juli 2017

UU No 23 Tahun 2002 Pasal 4 Tentang Perlindungan Anak

Nurussama, Alfiana. 2019. Peran Guru Kelas Dalam Menangani Perilaku Bullying Pada Siswa. Jurnal Pendidikan Guru Sekolah Dasar Edisi 5 Tahun ke-8 2019.

Yunika, dkk. 2013. Upaya Guru Bimbingan Dan Konseling Dalam Mencegah Perilaku Bullying Di SMA Negeri Se Kota Padang. Konselor. Jurnal Ilmiah Konseling. Volume 2 Nomor 3 September 2013
Yenes, Ilfajri. 2016. Perilaku Bullying dan Peranan Guru BK/Konselor dalam Pengentasannya (Studi Deskriptif terhadap Siswa SMP Negeri 3 Lubuk Basung). Konselor. Volume 5 Number 2 June 2016 ISSN: 1412-9760

Trisnani, Rischa Pramudia \& Wardani, Silvia Yula. 2016. Perilaku Bullying Di Sekolah. GCOUNS Jurnal Bimbingan dan Konseling Vol 1 (1) Tahun 2016, ISSN, 2541-6782

Dwipayanti, Ida Ayu Surya \& Indrawati, Komang Rahayu. 2014. Hubungan Antara Tindakan Bullying dengan Prestasi Belajar Anak Korban Bullying pada Tingkat Sekolah Dasar. Jurnal Psikologi Udayana 2014, Vol. 1, No. 2, 251-260. ISSN: 2354-5607 